\title{
THE ARAB HALL: A SPATIAL READING FROM WITHIN
}

| Received January 6 ${ }^{\text {th }}, 2020$ | Accepted April 15th, 2020 | Available online December 15 $5^{\text {th }}, 2020$ | DOI http://dx. doi. org/10.18860/jia.v6i2.8340 |

Faredah Mohsen Al-Murahhem

Umm Al-Qura University

Saudi Arabia

fmmurahhem@uqu.edu.sa

\begin{abstract}
This study highlights a woman's impressions and experiences of the interior of the Arab Hall at Leighton House. It is a spatial reading of the Hall from within, as an Arab and a Muslim. A woman who comes from this culture and has experienced at first hand the general ethos of imaginary interior scenes with lack of a complete understanding of such cultural context. The study focuses on the identity of the Arab Hall and examines its interior from these standpoints. It explores the origin of some artifacts of the Hall and the East's impact on Lord Leighton. It investigates the authenticity of the hall and whether it is of an Islamic or Arabic interior via encountering the Hall architectural elements with some Islamic historical sites that Leighton visited. The analysis dives deep into the usage and the staging of these artifacts according to the Arabic culture. More importantly, this study states -for the first time-the mistreatment and misuse of some of the Quranic Phrases.
\end{abstract}

\section{KEYWORDS:}

Arab Hall, Lord Leighton, Islamic influence, Arabic culture, East

\section{INTRODUCTION}

The Hall is located in Lord Leighton's House on 12 Holland Park Road in Kensington in London. The house is now open as a museum is run by the Royal Borough of Kensington and Chelsea. It was the projected window that is overlooking the Hall which brought the researcher to the Arab Hall. This was in 2002 when the direct involvement with the Hall began as part of a doctorate thesis-to an Arab, being within the Hall, the scenery evoked memories and feelings beyond expectations. With surprising eyes observing hungrily, exclaimed: "What is this doing here!". It was the impression of being within such an exotic milieu. There was no answer, but a mere overwhelming and silent observation. It was like trying to examine the reality of the space and the artifacts in particular. The whole milieu, the colors, and the touches triggered memories and nostalgia. Would it be possible to hear noises, evoke stories, or what? It was nothing but feeling at home and far away from London. There were memories of Damascus, as the tiles' color evoked such scenes. Whereas, dark wooden screens triggered memories of Cairo. There were mixed feelings, blurred minds, and a big question: Is this a house, a madrasa (school), or a shrine? In the end, feelings with regards to the whole milieu and being within it were enigmatic.

Doubtless, for Arabs, it is obvious to say that this hall might be in Cairo or Damascus or anywhere in the Arab world. But why Damascus and Cairo? Is it be- cause of the tiles, the color scheme, the Arabic calligraphy, the ornate decorations, or the merger between these features? Basically, "What is Arabic in here?"; more precisely, "What is not Arabic here?" Was it authentic to call it the Arab Hall, where the Arab traditions and lifestyle were reflected? For instance, the first striking impression, to an Arab, was that of the small wooden panels half-closed off the seating areas. A significant factor in the Arab cultural customs is the great significance of hospitality, whereby the panels' existence to prevent sitting would not be accepted. For Leighton, such an element may be used for privacy, but not to sit on the seat. For Arabs, having a seat in a hall used as a reception area with a partition to close the area is not authentic.

Consequently, the study highlights Lord Frederick Leighton and the Hall's background alongside the impact of the 'Arabian Nights' as a fantasy that dominated the period in which the Hall was built. The investigation includes his travels to the East and Leighton's letters that documented his journeys. These factors with some of his paintings, depicted the East play a significant role in finishing the last picture of the Hall. The process is to bring the visual language of Leighton's memories in texts and images to be observed and examined. It is a narrative journey to visualize how Leighton's dream of the Arab Hall comes true. The study also encounters the Hall architectural elements with some historical sites from the Islamic world and Leighton's diaries and letters. Leighton's paintings of the 
East, and Damascus in particular, even after he returned, were also another factor to compare. Finally, the study focuses on some of the artifacts' interpretation from a different perspective; that is the point of view of the owner of the Hall and the researcher. It is a discussion of different aspects of the Hall through the eyes of a female researcher who comes from an Arab and a Muslim culture.

\section{METHODS}

The study investigates the authenticity of the Arab Hall via encountering the Hall architectural elements with some Islamic historical sites where Leighton visited. The analytical methodology is the core of the study, where the usage and the staging of these artefacts are tested according to the Arab culture. Leighton's letters that document his journeys to the East bring the owner's perspective. Whereas his background and paintings illustrate another dimension to the analysis.

\section{DISCUSSION}

\section{LORD FREDERIC LEIGHTON}

Returning to the mystery of the Hall's owner, Frederic Leighton was born in Scarborough, Yorkshire, in 1830. He was Lord Leighton, the painter and, later, the president of the Royal Academy. In 1838, he enrolled at University College, London, for one year, and then traveled with his family through Paris, Rome, then through Germany and Switzerland, from 1839 to 1841. However, in 1852, Leighton arrived in Rome with his imagination filled with images of the Early Renaissance in Italy inspired by his movement within a large artistic circle, including the novelist William Thackeray (18111863) and some of the most important French painters of the time. His friendship with the architect George Aitchison (1825-1910) and other friends was dated back to 1853 . After returning to England, Leighton was elected as the Royal Academy associate in 1864 and became a full member in 1869 [1].

In the same year, Leighton went to Vichy and met Richard Burton (1821-1890), which marked the start of their friendship. Burton was the translator of the 'Arabian Nights' and the traveler who was infamous for entering Makkah and Madinah's sacred Islamic cities in 1853. This friendship was a fortune for Leighton, as Burton played a role in completing the Arab Hall, and since Leighton was an affluent collector and Burton was a British Consul in Damascus. Between 1870 and 1871 , Leighton started the first of the annual musical parties, which became one of the season events, since dinners, parties, and studio visits of eminent or wealthy individuals became necessary elements in the road success [2]. In 1878 Leighton was elected as the president of the Royal Academy. It was followed by another recognition of his work in 1894 when the Royal Institute of Architects awarded him a gold medal. In 1896 he became a baron "Baron Leighton of Stretton"; being the only English artist to receive this honor. Unfortunately, this was a shortlived honor as he died on January 25 that same year [1].

\section{THE ARAB HALL}

The Arab Hall is on the west side of Leighton's house, currently a museum on 12 Holland Park Road in London (Figure 2, Figure 8, Figure 9 a). It was as early as 1857 when his own house's dream, and most importantly, his 'Arabian Nights' dream started to take shape. In 1864 Leighton commissioned George Aitchison to build the Hall, and Leighton moved in, in 1866. From 1864 onwards, he traveled to specific places in the East to collect artifacts and experience architecture. When the Hall was completed in 1881 , it was used as an after-dinner smoking room, as Daniel Robbins claims. Robbins is the curator of Leighton's house, who the researcher interviewed in 2005 [3]. He argues that the Hall was not built primarily to fulfill a practical function; it was more of a memorable setting for the tiles' display and an enjoyable project for both Leighton and the architect George Aitchison. Robbins also claims that it would be wrong to imagine that Leighton and his friends then played out an Arabian Nights fantasy within its walls [1][4].

The whole milieu evoked such a scene, which made Robbins' claim hard to believe. Studies of the Orientalists also stress the Orient's impact and ensure that traveling to the East would feed this hunger. For instance, some scholars argue that amongst the artists who played a role in introducing an Oriental theme of living is Lord Frederic Leighton [5]. Others claim that "the best known of the official painters, Lord Leighton, came back from the Levant with enough columns, ceramics, and basins to build an Arab Hall in his Kensington studio"[6]. Undoubtedly, Arabian Nights played a significant role in Victorian society as an image from the East. On the contrary, and based on the experience of visiting the Hall during that time, Harry How said in 1892:

"One can only stand and listen to the splashing of the fountain falling beneath the golden dome at the far end of the court, and conjure up recollections of the fairest of scenes and grandest of palaces described in the Arabian Nights. We are in Kensington, but as one stands here, it would not come as the least surprising if the court were suddenly crowded with the most beautiful of Eastern women reclining on the softest of silken cushions in the niches in the corners; if the wildest and most fascinating dancers of the Arabian Nights were to come tripping in, and to the sound of sweetest of strains glide across the smooth plaques." [7:197]

Harry How described the evocation of these

84 | Journal of Islamic Architecture, 6 (2) December 2020 
tales when he visited the Hall. He admitted that the setting conjured scenes from Arabian Nights, and he completed the evocative fantasy panorama with Eastern women and dancers from Arabian Nights. The impact of the Arabian Nights was eminent by that time, and Leighton was no exception. He expressed his admiration in a letter to his friend, dated 22 October $\mathbf{1 8 5 7}$, as Leighton wrote:

"I have just come back from Africa, where I have spent some weeks with extreme pleasure, and, I believed, not without great benefits; indeed, I might say that an artist cannot perfect his sense of form so well anywhere as in the East! however, I believe I have learned a great deal by my observations." [8:vol1:304].

The Arab Hall, often used by Leighton as a gentlemen's smoking room, was also open to visitors. However, the room with the projected lattice window, which overlooked the Arab Hall, was used as a small painting room. In a letter to Leighton's friend Octavia Hill (1838-1912), who did charity work, he wrote: "you and your friends, the poor people from Whitechapel will be very welcome to the Arab Hall and Ground Floor in my absence- they may see everything but the studio" [9:24]. This part of the house which Leighton classified as the studio completes the scene of the Hall similar to the $q \bar{a}^{c} a$ (in Arabic). Behind the projected lattice window from above is a panoramic view with the fountain beneath that evokes Arabian scenes more.

The Hall's whole atmosphere looks like a big room or a $q \bar{a}^{c} a$ in the Arab traditional houses. The $q \bar{a}^{c} a$ is a big room with a high ceiling (of two stories height) which can be used as a reception for guests or family gatherings and parties. The $q \bar{a}^{c} a$ is a roofed courtyard with a fountain in the middle, a shared space of the Arab house, and inspirational to most Orientalists who travelled to the East. The layout and Arabic features of such a space were likely to include raised seating areas by latticed windows. Lattice screens in upper floors overlooking the activities beneath are used to seclude women and allow them to see, but not to be seen. The Hall's layout is similar, if not identical, to the $q \bar{a}^{c} a$ with two seating areas on both sides of the Hall and a display cupboard in the front elevation, and a fountain in the middle.

\section{THE ARAB HALL VS. THE JOURNEYS TO THE EAST}

One could rather rely on Leighton's own contemplation and his accumulated memory and nostalgia of his previous journeys to the East. However, some of Leighton's paintings reflect the link between his travels and his letters from the East. When Leighton mentally planned the Arab Hall, he needed to contemplate all his journeys to the East to come up with the final format, that is the Hall. Memories from these trips (Damascus, Algeria, Cairo, and Turkey), with an Eastern flavor and nostalgia from his own
Arabian Nights, were triggers to conclude this long-life project. He planned it from the first visit to the East to have his setting similar to his peers who traveled to similar cities. Simply he was trying to mimic what he had experienced in his journeys. In 1857, when Leighton was in Algeria, he was keen to observe the Arabic way of domestic living in what he called the Moorish interior. Leighton managed to get into one house that he described to his mother, saying:

"... Of course, one of my great desires was to see if possible a Moorish intérieur; and in this, though it is difficult to achieve, I have been very fortunate, through the instrumentality of a young native, with whom I became accidentally acquainted. I have made the acquaintance of one Achmet, son of Ali Pasha, I have been twice to his house, which I may as well describe to you, as it is a type of all Moorish houses in this part of the world. The whole of the building center is taken up by a little cortile, open to the sky and surrounded by two storeys of arcades of a graceful shape, on to which the room open as in Greek houses. These arcades are painted pure white and are relieved by fillets of colored porcelain tiles with the most original and charming effect. The first-floor gallery is closed in by a breasthigh balustrade, elegantly carved and painted blue or green; the top of the house is invariably an open terrace, adorned with flower shrubs. I said the rooms open on the corridors and have no windows (except little peeping holes) on the street; they are consequently always wrapped in a clear, cool, reflected twilight that is inexpressibly delightful and soothing in hot, glaring weather. Each room takes up one side of the house. Therefore, it is a long narrow strip; immediately opposite the door is an alcove, containing a raised, handsomely cushioned and carpeted divan, and ornamented invariably with three florid gilt lookingglasses. At the foot of the raised divan is another lower one for those who like low seats; other such divans run along the wall. A few highly wrought, embossed chests and other oriental articles of furniture complete the room's decoration. You would have laughed to see your son lolling on a Turkey carpet and puffing away at a long pipe." [8:vol1:300-302].

This experience was the trigger that played a significant role in Leighton's daydreams and led to the building of the Arab Hall. Leighton devoted these years of his life immediately after this journey to build his dreams' architectural reality. Many factors helped to transfer this project from paper to a real model. When Leighton generalized about the Moorish house in his letter, saying, "as it is a type of all Moorish houses 
in this part of the world," he was looking for a typical setting to work. His dilemma lay in the inherent contradiction between his conception of the relationship between a real Arab interior and the 'Arabian Nights' fantasy.

Comparing the description in his letter with the Hall itself illustrates his joy at living this dream; as he expressed to his mother saying: "You would have laughed to see your son lolling on a Turkey carpet and puffing away at a long pipe." It also demonstrates the specific features he wanted to incorporate into his house. He indicated these hints; the tiles, alcoves with raised divans, and even the color scheme. Leighton admitted that he visited the Moorish house of the Pasha twice. It may have helped to engrave the image in his mind intensely. Based on his admiration for the East and his desire to visit the Moorish interior, Leighton started his journeys to liven such scenes.

It was as early as 1857 when the dream of his own house, and most importantly, his Arabian Nights dream started to take shape. On the contrary, some scholars state that Leighton was already thinking about acquiring large architectural panels of tiles as early as 1869 , which implies that he had already conceived the idea of adding an Arab Hall to his house in Holland Park [9]. Even though Leighton commissioned George Aitchison to build his house in 1864, he went intensively and intentionally to specific places in the East, aiming to collect artifacts and sketch architecture. The timeline of his journeys since he built his house speaks for itself and complete the story. For instance, in 1866, Leighton visited Spain and made sketches of architecture in Toledo, Seville, and Cordoba. Why these cities in Spain in particular? Simply why Islamic? Was it because of its Eastern impact? They were not Arab cities, but they were under the Islamic dynasty for ages, and they were easy to visit.

The following year Leighton went to Constantinople (Istanbul), Broussa (Bursa), and Smyrna (Izmir) in Turkey. He visited Rhodes in Greece and other parts of Asia Minor and bought Persian plates. From that trip, in 1867, he depicted a scene in Broussa, Courtyard of Mosque at Broussa of 1867 (Figure 6). This painting illustrated the fountain in the courtyard and the tiles in the raised arched area. The actual building, which still exists, is known as the Muradiya Complex. The Muradiya complex of Murad II is located on Murat street in Bursa in Turkey (Figure 1, Figure 3 , Figure 5). The complex was built in the $15^{\text {th }}$ century with an Islamic style that reflects the Ottoman period used as an educational, religious, and funerary building. It was a madrasa or an educational place, a masjid (mosque), and a mausoleum where Murad II was buried [10]. This complex is an Islamic icon that reflects a specific period. Therefore, its features and artifacts are Islamic and not Arabic.

It was not a coincidence that the Muradiya looks like the Arab Hall. Signs could be spotted in comparing Leighton's paintings to the Arab Hall in particular. The similarities between the complex and the Hall are amazing in terms of color, pattern, and exterior shape. Yet why he visited this ruined complex? Was it possible at that time to collect materials from there? What was it about this tumble-down, nondomestic place which inspired Leighton and, more precisely, how did these features feed into the development of the Arab Hall? A comparison of the two buildings shows the resemblance between the outside form of the mausoleum's domed octagon and the Arab Hall. Although the form of the first building is octagonal, the Hall is square in plan, but with the shape of the extended seating area it looks similar (Figure 1, Figure 2). However, the octagonal shape is used as a treatment transition from the plan to the dome's circular base. The striped pattern in the bricks' arrangement is reflected in the painted stripes, which decorate the interior of the Hall. This feature was common in Islamic cities such as Turkey and Syria, including the house Leighton stayed in during his visit to Damascus.

The use of blue tiles in the complex is more pronounced in the lower part of the mosque's interior walls and the madrasa (Figure 3). In the Arab Hall and the hall leading to it, blue tiles are the primary treatment of the interior walls, mimicking some original Iznik tiles in Leighton's collection (Figure 4). The fountain in the complex's courtyard is another feature that illustrates echoes in Leighton's memory and flashes back to the house he stayed at in Damascus. The fountain in the madrasa's courtyard is depicted in the painting Courtyard of a Mosque at Broussa, dated 1867 (Figure 5, Figure 6). Most of the Islamic buildings Leighton sketched, including those he visited in Spain in 1866, incorporate this distinctive Islamic architecture feature. The scene was influential, did not easily fade from Leighton's memory, and reverberates in his design of the Arab Hall.

In 1868, Leighton visited Egypt and cruised up the Nile by boat, experiencing the atmosphere of actually being in the Pasha's Palace [8]. Now he had seen a real character from the 'Arabian Nights', the Pasha, in action. The rest could be linked to his long-standing dream. Another experience of his journey may have added a further layer to his imagination; this time of being in a domestic building, where he may have encountered a reception hall known as a $q \bar{a}^{c} a$. In 1869 , Leighton went to Vichy in France, where he met Richard Burton, the traveler and translator of the 'Arabian Nights', and their friendship began. This friendship was fortunate for Leighton, as he had the right man for the right mission. He made impossible things manageable since Leighton was a well-paid collector and Burton was a British Consul in Damascus. Burton wrote to Leighton on March 22, 1871, from Damascus:

"I am quite as willing to have a house pulled down for you now as at Vichy, but the difficulty is to find a house with tiles. The bric-a-brac sellers have quite learned their value and demand extravagant sums for poor articles. Of course, you want good old specimens, and 
these are waxing very rare. My friends, Drake and Palmer, were lucky enough when at Jerusalem, to nobble a score or so from the so-called Mosque of Omar. Large stores are there found, but unhappily under the Wakf's charge, and I fancy that long payments would be required. However, I shall send your letter to my colleague, Moore, who will do what he can for you. The fact is, it is a work of patience. My wife and I will keep a sharp look-out for you and buy up as many as we can find, which seem to answer your description. If native inscriptionswhite or blue, for instance-are to be had, I shall secure them, but not if imperfect. Some clearing away of rubbish is expected at Damascus; the Englishman who superintends is a friend of mine, and I shall not neglect to get from him as much as possible." [8:vol2: 218-219].

It seems like an easy job as long as money is concerned. Everything is in reach, even from mosques as expressed in Leighton's letter as "... lucky enough ... at Jerusalem... Mosque of Omar". However, feelings are more than remorseless to be expressed for a Muslim reading such a scene. Artifacts could be from anywhere, even from worship places as a mosque (masjid). A specific image is to be fulfilled, regardless of its status (house, tomb, worship place). Amazingly, Burton was ready to pull down a house for Leighton when he stated, "now $=1871$ as at Vichy $=1869$ ". The letter highlights the destination, the tile collection, and the color scheme preferred. Burton noted the exact target to complete Leighton's setting: the tiles and the native inscriptions. The latter may indicate a lack of knowledge of Arabic scripts. These scripts may be poems or Qur'ānic scripts that reflect the function of the palce and the entire site. It is another issue that raises a debate of the Hall name's authenticity as the Arab Hall.

Two years later, Leighton visited Damascus in 1873 and bought plates and tiles, when Burton was not a Consul there. He contacted Burton's friend; Dr. William Wright (1810-1870) was an Irish amateur archaeologist who spoke fluent Arabic and had lived in Damascus for a long time. Wright eventually played a significant role in securing most of the artifacts for the Hall. Leighton searched for oriental draperies with him but was mainly interested in tiles, plates, and long -necked jars with a blue background and white flowers. It was the color scheme he was looking for in his collection, including the tiles. Within a few weeks, Leighton was able to lay the foundation of his fine collection. Another friendship secured the tiles of the Hall, where Wright continued to supply materials from Damascus. He then gave his collection to Leighton [1]. Burton summarised previously how to complete this mission of securing Leighton's request based on money, networking, and time as he wrote, "...long payments would be required. I shall send your letter to my colleague, The fact is, it is a work of patience".

Accordingly, Leighton bought some artifacts from Damascus, depicted two main scenes, and got some important paintings that connect with the Hall. His most important painting connected with the Hall is Old Damascus: Jew's Quarter in 1873 (Figure 7). This painting renders an actual scene from the house where Leighton stayed in. The house is believed to be Farhi House, which may still exist and is known as 'Dahdah Palace' in the Jewish quarter in Damascus [11]. The comparison between the Farhi House and the Arab Hall is instantly recognizable, and the visual language speaks for itself. For instance, the courtyard with the fountain in the middle, the striped wall treatment, arches with floral and geometrical ornamentation, and woodwork in wardrobes, to some extent, are similar. The eminent feature is the fountain, which completes the scene and gives the fourth dimension to the space. As an architectural element used in domestic buildings, his admiration of the fountain is documented in Leighton's letter to his father describing the court, the interiors of the old houses, including the marble floors, the vivid, sparkling leaves, and the unceasing song of the bubbling fountains [9].

The painting Old Damascus: Jew's Quarter is believed to have been painted to document Damascus' architectural features. The painting's real subject is undoubtedly the building - an incredibly elaborate example of wall-painting and tile-work. The courtyard has a surprising variety of asymmetrical arches, doorways, and windows, with equally complex patterns striped, circular, floral, and geometric [9]. Therefore, it is not difficult to notice the similarities between the Arab Hall architectural features and this painting; the striped marble, the woodwork, the use of color, the arches, the niches and the ornamentation, and above all, the concept of the courtyard and its privacy. The niches, on both the wall and the wooden wardrobe, provide another dimension, which helps to complete the Eastern scene.

This Oriental flavor based on the Farhi house is also repeated in another painting, The Music Lesson of 1877. The painting depicts the house and part of the raised seating area by the court with a fountain in the background, where striped marble and niches in the wall complete the setting. The Hall's pre-eminent feature is the fountain, which completes the scene and invokes sound like a fourth dimension to this scene, just as he had often narrated in his paintings. The fountain that Leighton described to his father is depicted in another painting; Fountain in Court at Damascus, 1873 [12]. It is another painting that documented the same house. Leonée Ormond also believes that this painting is depicted to document the architectural features of Damascus. He states that the real subject of the painting is undoubtedly the building [9]. Nothing may justify this action rather than passion and nostalgia. The house architectural features were scattered in Leighton paintings, until he had his own version to live in.

Sir Caspar Purdom Clark (1846-1911) was another active figure in collecting materials for the Arab Hall. He was the South Kensington Museum director 
and was commissioned in 1876 by the Museum to travel to Greece, Turkey, and Syria to collect 'art objects.' It was a great chance for Leighton, who asked Clarke to go to certain houses in Damascus and purchase certain tiles. By that year, Clarke and Burton managed to buy tiles on Leighton's behalf from Damascus and other places [5]. It is believed that the architect Sir Clark and Burton bought tiles on Leighton's behalf from Damascus and other places. More importantly, Burton traveled to Makil Hill on the Bank of Indus River and made a small collection. Five years after, the job was accomplished, and Burton sent Leighton a letter on 13 of July 1876 from Trieste saying that:

"MY DEAR LEIGHTON - One word to say that the tiles are packed and will be sent by the first London steamer-opportunities are rare. Some are perfect, many are broken, but they will make a bit of mosaic after a little trimming and illustrate the difference between Syriac and Sindi. They are taken from the tomb (Moslem) of Sakhar, on the Indus. I can analyze glaze if you want it, but I fancy you don't care for analysis. The yellow color is by far the rarest and least durable. The blues are the favorites and the best." [8:vol2: 219].

From a tomb! No wonder that this was the researcher's unusual impression in the first visit. This may explain the inappropriate scripts and the incorrect tiles' positions, being collected from a masjid and a tomb. Burton indicated that many of the tiles were broken, but they will make a bit of mosaic with a little trimming. Unfortunately, tiles with scripts were used merely as artifacts with no valued respect. Simply, because most of the collected scripts were not a poem nor ordinary Arabic phrases, these native inscriptions were from the Qur'ann - the Muslim holy book. Evidence of the originality of some of the tiles, as Burton mentioned, as Syriac and Sindi, shows the Hall's overall theme. It could be the case for most tiles, as it seems easy to get more tiles from a tomb than from a masjid. That is Islamic; this makes different specimens of tiles fit together perfectly as if they come from one place. The overall stamp of the Hall is the Islamic spirit; basically, this is the tie between all collected artifacts. These artifacts should go with the others that Leighton collected earlier from Turkey, Cairo, Damascus, or any Islamic sites. The common feature shared by these destinations is the Islamic characters that melt them into one pot.

The Arab Hall was planned and commissioned by Aitchison in 1877 . The artifacts were ready, and the architect was already chosen, even though Aitchison has more experience in industrial buildings than domestic. Leighton was more than ready, as he had the visualization of his dream home. That was due to his passion for the East and his admiration of the Moorish interior, as he previously described in his letter to his

mother. In October of the same year, Leighton went to Spain, then Tangiers - Morocco. The last touches for the Hall were to be put and checked visually to reach satisfaction. That is, scenes were examined with relevant views from their origins. In 1879, the Arab Hall and some other parts of the house were completed. However, some small details were not completed till 1881 [1]. Despite that, when the repair work was completed virtually in 1947, nothing remained of Leighton's house's original decoration except the Arab Hall [13].

The East dominates Leighton's nostalgia as he keeps that link till the last days of his life. He said that while he was in Algeria and fell in love with these scenes from the first sight, he wrote, "This visit made a deep impression on me, I have loved the 'The East' as it is called ever since." This was in a letter to Mrs K. Pattison in 1879, referring to his first visit to Algeria [8]. In another letter to his sister, he wrote, "Since I last wrote I have spent a month or six weeks in Algeria, and have opened an acquaintance with the East which I hope to keep up, not only from the pleasure but from the instruction I have derived from even a short visit" [8]. Leighton kept his promise to maintain this link with the East because even after he finished the Hall, he returned to Egypt in 1882 [14]. Moreover, in 1895, he traveled to North Africa (Tangier, Telmcen, and Algiers) for relaxing, and that was exactly a year before he died on January 25, 1896.

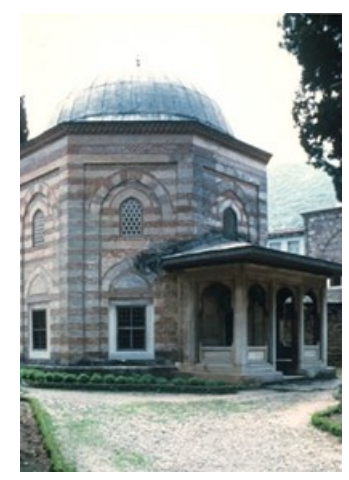

Figure 1. The Muradiya Complex - Exterior Form [15]

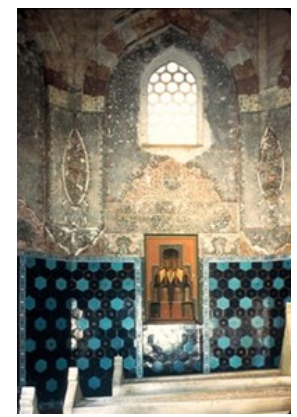

Figure 3. The Muradiya Complex - Tiles [15]

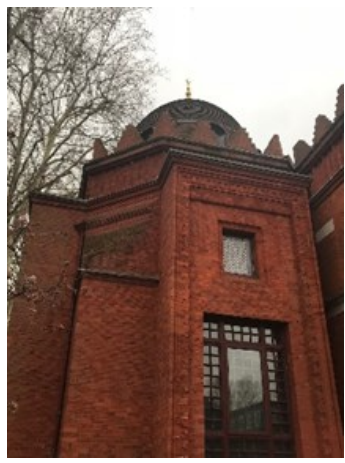

Figure 2. The Arab Hall Exterior Form [The author]

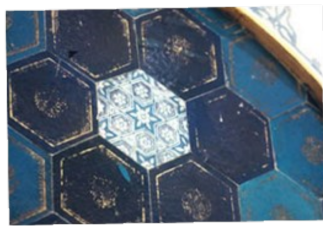

Figure 4. Tiles in the Arab Hall [13] 

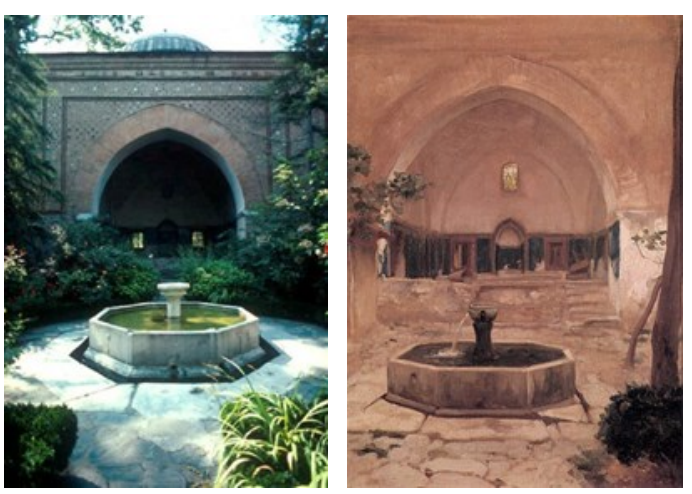

Figure 5. The Muradiya Complex - Fountain [15]

Figure 6. The Courtyard of a Mosque at Broussa, 1867 [9]
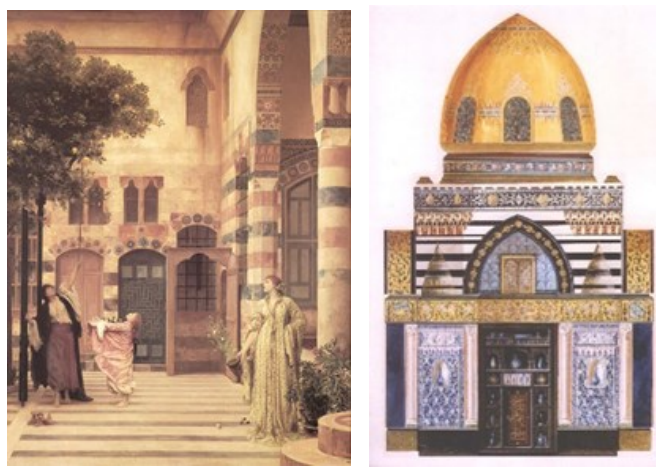

Figure 7. Old Damascus:

Figure 8. The Façade of the Jew's Quarter, 1873 [9] Arab Hall (RIBA Collection)

\section{ARTEFACTS AND AUTHENTICITY}

The matter is debatable when it comes to the authenticity and originality of the whole milieu. Although Leighton tries to bring original artifacts to enhance the final outcome of the Hall, the Hall's appearance reflects the artist's interpretation. For the researcher, it was quite a blurred feeling, whether it was frustration or joy. The frustration of seeing original artifacts away from home in a different context and the joy of the memories, and nostalgia evoked by the milieu being in a homeland. Here are some cases that analyze the treatment and the staging of the artifacts within the Hall. It demonstrates misuse and lack of knowledge of the Arabic culture, which the researcher observed amid multiple visits:

1. The first impression that may strike an Arab the most is the wooden small panels half closed in the alcoves' seating (Figure $9 \mathrm{~b}$ ). It could be quite understandable if the red robe is located for protection, but it seems not. The great factor in Arab cultural customs is the significant attention given to hospitality, even if the guest is an enemy of the household. A scene like that could be designated as offensive; that is to put barriers in front of the seating area. It would be perceived as an unwel-

coming gesture, especially in a reception area. The wooden panels might be authentic artifacts but are subject to a non-authentic understanding of convention (Figure 9 a).

2. The hanging light fitting resembled, far more closely, the chandeliers found in mosques rather than their domestic equivalents (Figure 9 a). This circular brass chandelier could influence Leighton's visit to the Grand Mosque in Damascus as he depicted "The interior of the Grand Mosque of Damascus" in 1873. He previously depicted another sacred scene in Turkey of the Courtyard of a Mosque at Broussa in 1867 (Figure 6). The chandelier could be an authentic artifact from one of the sacred old sites that Burton or any of Leighton's friends had come across or managed to get. With the function to light a bigger interior, such an element would be in a public space rather than a house.

3. This case is based on the regular visits to Leighton House and the analysis of the setting in the Arab Hall. The researcher realized that one of the framed Arabic phrases, mainly the Qur'ānic script, was not in the correct order. It looked odd at the start; the tiles and the script were treated as motifs. The panel was located on the left side of the front wall of the entrée. It is situated on the top of the built-in shelf. There are two similar panels on both sides of the wooden cupboard, each with different scripts (Figure 8 ). This observation calls for an in-depth analysis of both panels. It started with the tiles' panel with scripts on the middle wooden cupboard's left side. A missing tile is replaced with another one that changes the phrase's meaning (Figure $10 \mathrm{a}$ ). It was the clearest one that could be noticed by any Muslim who reads the Qur'àn if one could just pay attention. In the upper part of the panel is written: "Acauzo Billah min ...", the last word "Alshaytāan" is missing (Figure $10 \mathrm{~b}$ ) and is inappropriately substituted with another tile. In the raw beneath, the phrase is completed with the word "Alrajeem" and the phrase "Bismillah Al- Rahmān al-Raheem". The term missing, "Alshhaytān," is replaced with another Qur'ānic phrase, "Qad Tabayan," which is part of a phrase (äyah) 256 in Surat al-Baqara. The actual correct phrase means, "I seek Allah's refuge and protection from the Satan," which symbolizes the commencement phrase that is cited when one starts to read the Qur'ān. Surprisingly, the missing tile was located wrongly in the other panel on the right side of the cupboard (Figure 11). This panel is another treatment that needs an in-depth analysis where the tiles are placed in the wrong positions. The phrase in this panel is incorrectly read. The phrase has to start from the right side, as in Arabic. On the upper part, tiles number 1, 2, and 3 should come first. Then the phrase should continue from tiles number 4,5 , and 6 at the bottom. Consequently, tile number 3 is the missing tile for the other panel, as was previously discussed. 
Therefore, the phrase on the upper part is incorrect, and it reads "Astamsak bel 'urwati". However, tile number 4 is related to the upper phrase, and it reads "La infisām". The rest two tiles, numbers 5 and 6 , are not related and cannot be read correctly (Figure 11).

This shows how calligraphy in the tiles was treated in terms of ornament and relief rather than in relation to meanings or even respect for what it could or was meant to be. This mixing up of Qur'ānic phrases is inexplicable, as Leighton was surrounded by some friends who can understand Arabic. Though Burton said that the tiles would make a bit of mosaic with a little trimming, the mosaic on plain tiles would be different from those with Qur'ānic or religious scripts. The Qur'ānic phrases were employed as ornamental motifs to decorate the Hall without any attention to its authentic order or underlying meaning. The exploitation of these tiles represents nothing more than a fulfillment of the owner's passion. In other words, what could have been seen by the Orientalists or Western travelers merely as a visual cultural aspect would be a physical embodiment of Islamic obligation? Therefore, it may be the appropriate time to analyze such depictions from a Muslim perspective; if Leighton relied on these tiles with Arabic calligraphy to justify the name of the Arab Hall, how come that he did not even use it appropriately. Ultimately, what is written is not a poem or a meaningless phrase; instead, it is a religious phrase.

The tiles panel in Figure 10

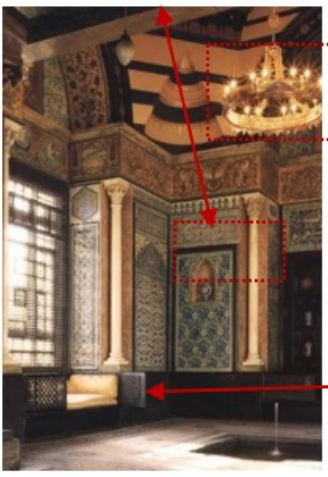

(a) (b)

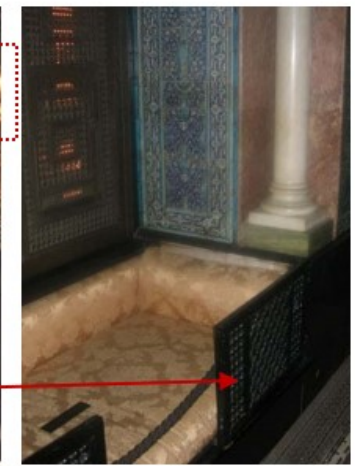

Figure 9. (a): The Arab Hall and the Artefacts. (b): Detail of the Wooden Panel (Barrier) in the seating area [The author]
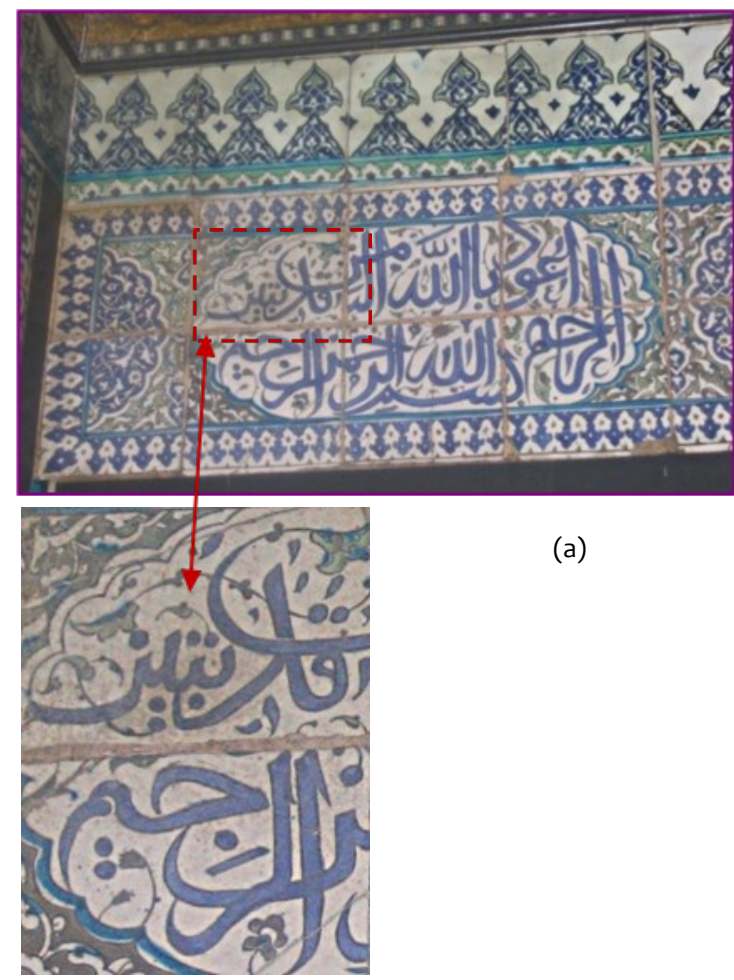

(a)

(b)

Figure 10. (a). Detail of the Tiles' Panel on the Left Side with the highlighted wrong tile.

(b) Detail of The Script of the missing tile that changes the meaning [The author]

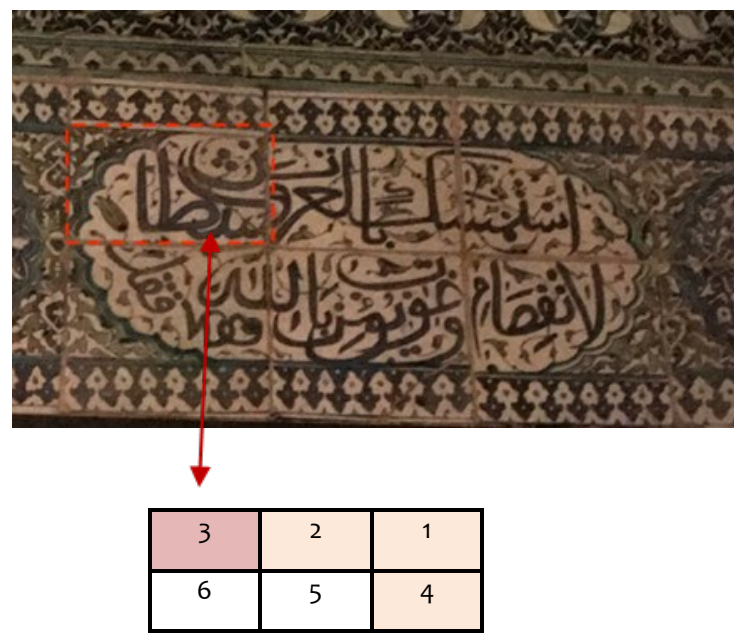

Figure 11. Detail of the Tiles' Panel on the Right Side with the tile that was missing from the panel on the left side of the Hall [The author]

\section{ARAB VS. ISLAMIC HALI}

The previous discussion illustrates signs of Islamic features in the Arab Hall. The Hall is Islamic more than Arabic. Referring to Leighton's advice to his students and young artists, he stated that excellent work 
is stamped with its author's personality. He then stressed that a true genius knows no hurry and that past ages' gathered experience is a precious heritage [16]. Leighton manages to bring Eastern artifacts, as a gathering of past experiences, to create his version of the Arabian Nights. Leighton patiently gathered materials and artifacts for the Hall when he traveled to the East. It looks that the Arab Hall is a result of following such advice. The Hall was a long-time project for Leighton and not just a setting for artifacts he collected and purchased from specific places. He chose the style he preferred, reflecting his advice to appreciate the past heritage, blended with the artist's personality that mirrors his passion. To create the desired milieu, Leighton drew on the images of his version of the East as it would be lived realistically.

Leighton's determination and payments for these species cannot be justified for having the Hall just to accommodate his collection, away from the original owner's personality and intention to create the appropriate milieu. Leighton visited Damascus to bring materials to the Arab Hall, despite the Islamic cities' hostility towards Westerners at that time. However, he returned with enough columns and basins to build an Arab Hall in his Kingston studio[6]. The collection is mostly Islamic, especially the tiles, which proves the big argument of the original Islamic essence, even as stated by scholars:

\section{"... While Frederick, Lord Leighton, a Royal Academician who made three journeys to the East, was fascinated by the Arab world that he altered his Kensington house (now a mu- seum) to incorporate an Arab hall. He also built up a considerable collection of Islamic ceramics and textiles, helped by the explorer Richard Burton" [17: 12]}

Witold Rybczynski claims that "When a house contains a collection of antique furniture, it is also reasonable to create an appropriate setting... they are intended primarily to create an appropriate mood" [18]. For Leighton, it must have seemed obvious to study the correct style to bring the collection to life. The Hall was the answer to all questions, more precisely; thinking about Islamic architecture was the answer to the scene he had in his mind. Leighton's journeys to Damascus feeds the final touches of his dreams. The Arab Hall was as much true as an imitation or setting of the Islamic interior. Mary Anne Stevens states: "A fanciful imitation of an Islamic interior, this contains tiles, stained glass, and woodwork brought back from Damascus, augmented by modern British furnishings designed in a matching style"[19]. Whereas, Michael Darby suggests that the Arab Hall remains perhaps the most enjoyable of all the Islamic interiors carried out in Britain in the second half of the nineteenth century[20].

The Arab Hall exhibits a false claim that the Hall is based on Arabic architecture more than Islamic. Islamic architecture is based on Islamic rules and doctrines. However, it is reflected in the materiality of the religious buildings and the fabric of daily life and domestic architecture. Deborah Howard also stresses the strong link of Islam to architecture when she writes that "In some respect, the religious basis of Islamic society itself generated a characteristic urban form, independent of historical or geographical location, acknowledging the complexity and variety of the urban patterns displayed in the Islamic world through space and time" [21].

\section{CONCLUSION}

This is the story of a man who wanted to be a mystery prince in a fairy tale; that is Arabian Nights. It is the story of a painter who devotes his life to bringing the East home, not as images in his paintings, but as experiences to his own daily life. Leighton wanted a real scene to be drawn with his interpretation. He was looking for original artifacts to enrich this dream to become a reality. No doubt that his journeys to the East, especially to Algeria, cast shadows on the Hall, recording stories from the East in brick and stone. The Hall as a whole was built in stages: stage one was visualizing the miliule and its essence since he visited the East. Stage two was collecting artifacts and materials as authentic as they could be. The final stage was to commission the right person to turn his dream into reality.

Leighton manages to bring Eastern artifacts, as a gathering of past experiences, to create his version of the Arabian Nights. The Hall records Islamic architecture that brings many cultures under the same umbrella of Islamic values and beauty. Shall the name of the "Arab Hall" justify the Hall? It would be rather called Islamic. Islamic characteristics are much evident. Leighton may have called it Arabic to justify his dream, more precisely his interpretation, or own version of the Arabian Nights. Rightfully, the Hall should be called an Islamic Hall rather than an Arab Hall to reflect the true nature of its spirit.

The story behind the artifacts being brought from the East, and their use is another dimension being tackled in relation to the Arabic culture. Undoubtedly, those who are neither native nor brought up in the Islamic culture with first-hand experience of its values are unable to give an authentic or convincing justification of its realities. Conclusively, though these artifacts' setting may be considered exotic enough to be staged in a museum, it could be interpreted as an offensive scene to both a native Arab and a Muslim in particular. The pioneer finding of the misuse of the Arabic scripts may lead to more in-depth studies of the ceramic panels and the Qur'ānic scripts exclusively.

\section{ACKNOWLEDGMENT}

The analysis of one part of the tiles' panel with the scripts, which is located on the left-hand side of the Hall, was the paper's main concept, namely "An Arab Woman within the Arab Hall." It was presented to the 
Association for the Study of Travel in Egypt and the Near East (ASTENE) in Manchester July 14-18, 2005, when I was a member at the association.

\section{REFERENCES}

[1] F. M. Al-Murahhem, "Behind the roshan: Visualising the roshan as an Architectural Experience in Traditional Domestic Interiors," University of Brighton, 2008.

[2] M. Girouard, "The Victorian Artist at Home: The Holland Park Houses- I," Country life, vol. 16, 1972.

[3] Daniel Robbins, the curator of the Arab Hall Museum, 2005, Personal interview by the researcher.

[4] T. Barringer and E. Prettejohn, Frederic Leighton: Antiquity Renaissance Modernity: Studies in British Art 5. London: Yale University Press, 1999.

[5] J. Sweetman, The Oriental Obsession: Islamic Inspiration in British and American Art and Architecture 1500-1920. Cambridge: Cambridge University Press, 1987.

[6] P. Jullian, The Orientalists: European Painters of Eastern Scenes. Oxford: Phaidon Press Ltd, 1977.

[7] C. Darkers, The Holland Park Circle: Artists and Victorian Society. New Haven: Yale University, 1999.

[8] R. Barrington, The Life, Letters and Works of Frederic Leighton, 2 Vols. London: George Allen, 1906.

[9] S. Jones, C. Newall, L. Ormond, R. Ormond, and B. Read, Frederic, Lord Leighton: Eminent Victorian Artist. London: Abrams, 1996.

[10] "Leighton House Museum: The Arab Hall," Leighton House Museum, Where East meets West. [Online]. Available: http:// www.rbkc.gov.uk/LHLeightonHouse/
HouseTour/arabhall.asp. [Accessed: 01-Jun2006].

[11] A. Farhi, "A description of the Farhi Houses in 18th \& 19th century Damascus," Le s F I e u r s d e L' O r i e n t, 2018. [Online]. Available: http:// www.farhi.org/Documents/Farhi_Houses.htm. [Accessed: 08-Aug-2004].

[12] E. Rhys, Frederic Lord Leighton: Late President of the Royal Academy of Arts - An Illustrated Record of his Life and Work. London: George Bell \& Sons, 1898 .

[13] R. Simon, Lord Leighton 1830-1896 and Leighton House: A Centenary Celebration. London: Apollo Magazine, 1996.

[14] R. Benjamin, Orientalism: Delacroix to Klee. Australia: Thames and Hudson, 1997.

[15] ArchNet Digital Library, Muradiya Complex, Bursa, Turkey [on line], 2004, Accessed October 10, 2004, available: http://archnet.org/library/sites/ one-site.tcl?site_id $=2878$

[16] ARC: Art Renewal Center, Lord Frederick Leighton: Advice to young Artists in 1893. http:// www.artrenewal.org/asp/database/art.asp? aid=14\&page $=1$

[17] L. Thornton, The Orientalists: PainterTravellers. Paris: ACR Poche Couleur, 1994.

[18] W. Rybczynski, Home: A short History of an Idea. London: Heinemann, 1988.

[19] M. A. Stevens, The Orientalists, Delacriox to Matisse: European Painters in North Africa and the Near East. London: Royal Academy of Arts, 1984.

[20] M. Darby, The Islamic Perspective - An Aspect of British Architecture \& Design in the 19th Century. London: Hazell Watson \& Viney, 1953.

[21] D. Howard, Venice \& the East. London: Yale University Press, 2000. 